\title{
ENVIRONMENTAL MONITORING PLAN FOR THE NIAGARA FALLS STORAGE SITE AND THE INTERIM WASTE CONTAINMENT FACILITY
}

Lewiston, NY

April 1986

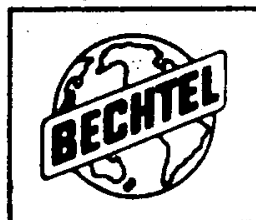

Bechtel National, Inc. Advanced Technology Division 
ENVIRONMENTAL MONITORING PLAN FOR THE

NIAGARA FALLS STORAGE SITE

AND THE

INTERIM WASTE CONTAINMENT FACILITY

APRIL 1986

Prepared for
UNITED STATES DEPARTMENT OF ENERGY

OAK RIDGE OPERATIONS OFFICE

Under Contract No. DE-AC05-810R 20722

\section{By}

Bechtel National, Inc.

Advanced Technology Division

Oak Ridge, Tennessee

Bechtel Job No. 14501

\section{DISCLAIMER}

This report was prepared as an account of work sponsored by an agency of the United States Government. Neither the United States Government nor any agency thereof, nor any of their employees, makes any warranty, express or implied, or assumes any legal liability or responsibility for the accuracy, completeness, or usefulness of any information, apparatus, product, or process disclosed, or represents that its use would not infringe privately owned rights. Reference herein to any specific commercial product, process, or service by trade name, trademark, manufacturer, or otherwise does not necessarily constitute or imply its endorsement, recommendation, or favoring by the United States Government or any agency thereof. The views and opinions of authors expressed herein do not necessarily state or reflect those of the United States Government or any agency thereof. 
ABSTRACT

As part of the U.S. Department of Energy's (DOE) Surplus Facility Management Program (SFMP), the Niagara Falls storage site (NFSS) is undergoing remedial action. Vicinity properties adjacent to and near the site are being cleaned up as part of DOE's Formerly Utilized Sites Remedial Action Program (FUSRAP). These programs are a DOE effort to clean up low-level radioactive waste resulting from the early days of the nation's atomic energy program. Radioactively contaminated waste from these remedial action activities are being stored at the NFSS in an interim waste containment facility (IWCF). When the remedial actions and IWCF are completed in 1986, activities at the site will be limited to waste management.

The monitoring program was prepared in accordance with DOE Order 5484.1 and is designed to determine the contribution of radioactivity from the site to the environs and to demonstrate compliance with applicable criteria. Major elements of this program will also supplement other monitoring requirements including the performance monitoring system for the IWCF and the closure/post-closure plan. Emphasis will be directed toward the sampling and analysis of groundwater, surface water, air, and sediment for parameters which are known to be present in the material stored at the site. The monitoring program will employ a phased approach whereby the first 5 years of data will be evaluated, and the program will be reviewed and modified as necessary. 


\section{DISCLAIMER}

This report was prepared as an account of work sponsored by an agency of the United States Government. Neither the United States Government nor any agency Thereof, nor any of their employees, makes any warranty, express or implied, or assumes any legal liability or responsibility for the accuracy, completeness, or usefulness of any information, apparatus, product, or process disclosed, or represents that its use would not infringe privately owned rights. Reference herein to any specific commercial product, process, or service by trade name, trademark, manufacturer, or otherwise does not necessarily constitute or imply its endorsement, recommendation, or favoring by the United States Government or any agency thereof. The views and opinions of authors expressed herein do not necessarily state or reflect those of the United States Government or any agency thereof. 


\section{DISCLAIMER}

Portions of this document may be illegible in electronic image products. Images are produced from the best available original document. 
3.1 Site Description 9

3.2 Site Environment 10

3.2 .1 Groundwater 10

3.2 .2 Air 11

3.2.3 Surface water 11

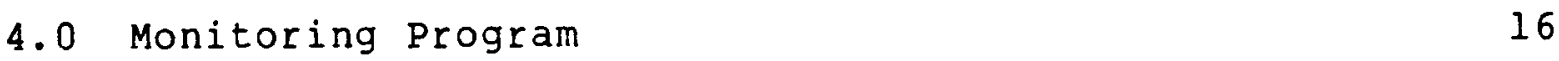

4.1 Groundwater 16

4.1.1 Groundwater Monitoring Locations 19

4.1.2 Sample collection and Analysis 22

4.2 Air and External Radiation 24

4.2.1 Air Monitoring Locations 24

4.2.2 External Radiation Monitoring Locations 26

4.2.3 Sample Collection and Analysis 26

4.3 Surface water and sediment 26

4.3.1 Surface Water and sediment Monitoring Locations 28

4.3.2 Sample collection and Analysis 28

5.0 Data Evaluation and Reporting 29

$\begin{array}{ll}\text { References } & 30\end{array}$ 


\section{LIST OF FIGURES}

Figure Title

$\underline{\text { Page }}$

1-1 NFSS Location Map 2

1-2 IWCF Plan View 3

3-1 Generalized Geologic section of the NFSS 12

3-2 Annual wind Rose for the NFSS, 1985

3-3 Surface Water Drainage at the NFSS 14

4-1 Environmental Monitoring schedule at the NFSS 17

4-2 On-Site Surface water and Groundwater Sampling Locations

4-3 Locations of Existing Groundwater Monitoring Wells and Wells to be Installed in FY 1986 at the NFSS

4-4 On-Site Radon Monitoring Locations 25

4-5. Off-Site Radon Monitoring Locations 27 


\section{LIST OF TABLES}

\section{Table $\quad$ Title}

Page

2-1 Radiation Protection standard and Radioactivity Concentration Guides for the NFSS

4-1 Monitoring Program for the NFSS

$4-2$

Recommended Groundwater Parameters for

Radiological and Nonradiological Monitoring

of the IWCF at the NFSS 
The U.S. Department of Energy's (DOE) Niagara Falls storage site (NFSS) is located in the Town of Lewiston, Niagara County, New York, approximately $32 \mathrm{~km}(20 \mathrm{mi})$ north of Buffalo, New York (Figure 1-1). The site has been used for storage of radioactively contaminated material resulting from uranium ore processing. As part of DOE's Surplus Facilities Management Program (SFMP), NFSS is currently undergoing remedial action. The cleanup of vicinity properties near the NFSS facility is being conducted under DOE's Formerly Utilized Sites Remedial Action Program (FUSRAP). All residues and wastes resulting from the remedial action will be stored at NFSS in an interim waste containment facility (IWCF) (Figure 1-2) which will be completed by the end of 1986. The IWCF will have a minimum design life of 25 years and a maximum expected life of 50 years with programmed maintenance.

An environmental monitoring program has been maintained at NFSS to determine the site's compliance with DOE Derived Concentration Guides (DCGs) (Refs. 1, 2, 3, 4, and 5). Sampling of air, water, sediments, and external radiation is being conducted on a routine basis. The existing program is the basis for the monitoring program presented in this plan.

This environmental monitoring program will be implemented after closure of the IWCF and remain in operation during management of the wastes and residues at NFSS. The report provides the regulatory basis for monitoring in section 2, a description of the facility and site environment in section 3, details of the monitoring program in section 4, and a discussion of the reporting requirements in section 5 .

Other monitoring activities will also be conducted at NFSS. A performance monitoring program will be conducted to verify that the main engineered elements of the IWCF are functioning as intended. 


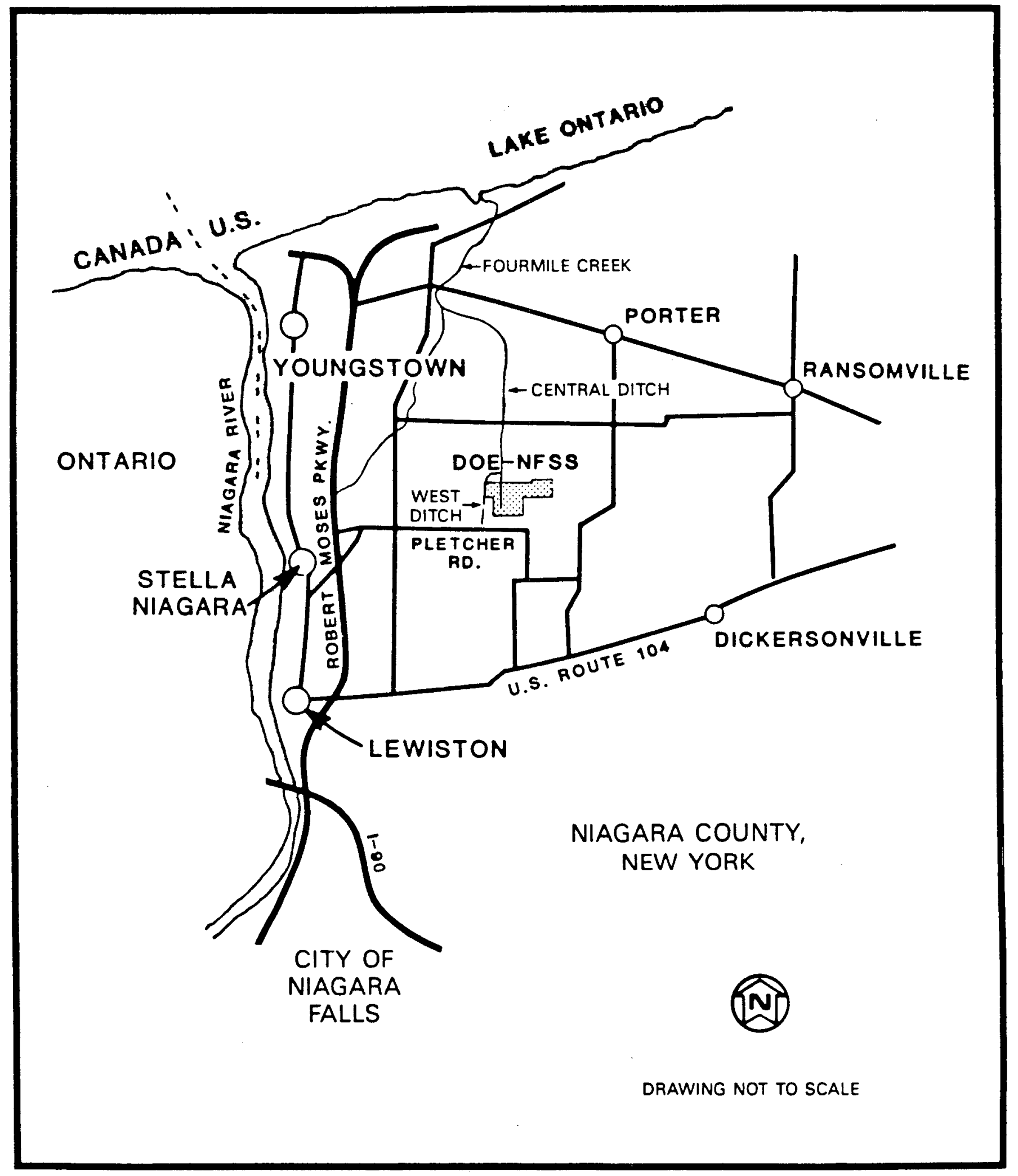

FIGURE 1-1 NFSS LOCATION MAP 


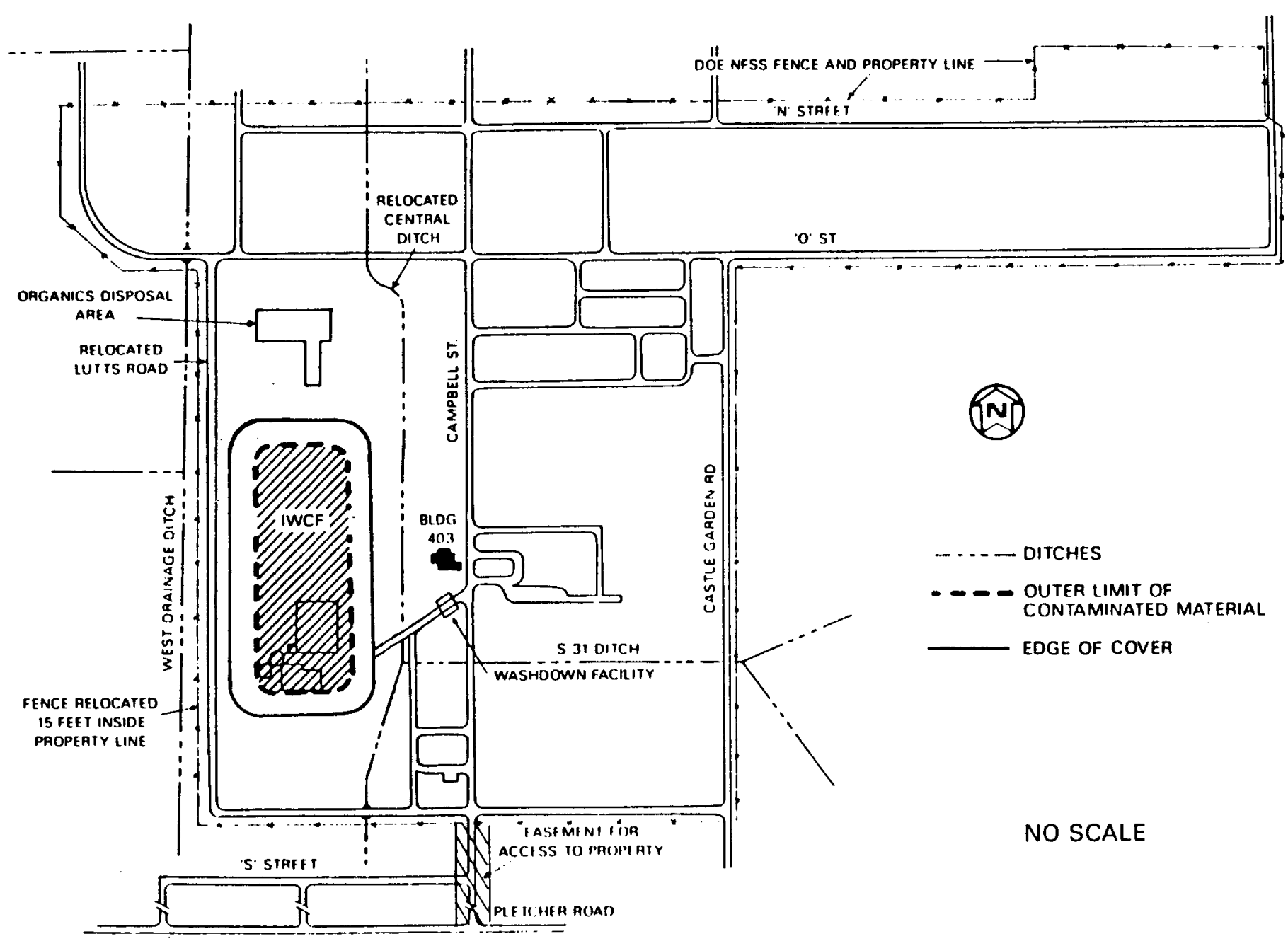

FIGURE 1-2 IWCF PLAN VIEW 
This program is discussed in detail in Reference 6 . Monitoring will be conducted to address the requirements of the closure/post-closure plan for the NFSS and IWCF (Ref. 7). 


\subsection{REGULATORY GUIDANCE}

Environmental protection programs for DOE operations are specifically provided for in operating "Orders." The applicable Orders focus primarily on radiological aspects of environmental protection. For nonradiological purposes, DOE is generally subject to the requirements of federal and state environmental laws.

\section{DOE Orders}

The environmental monitoring plan for the NFSS was prepared in accordance with DOE Order 5484.1 (Ref. 8). Consistent with 5484.1, this program has been developed to determine the following:

- Whether containment and control measures to limit releases of radioactivity from the site are functioning as planned

o Whether, and to what extent, environmental levels of radioactivity and other pollutants released from the site comply with applicable DOE guidelines

- What the overall impact of the site operation is on the environment

Broad guidance is offered in each of these areas which allows for the development of a monitoring program tailored to a specific site. Section 4 of this report presents the specific details as developed for the NFSS.

DOE's primary standards for radiation protection are contained in DOE Order 5480.1A, Chapter XI, "Requirements for Radiation Protection" (Ref. 9). However, DOE Order 5480.1A is being revised (Ref. 10). The revised radiation protection standard and the DCGs are summarized in Table 2-1. The DCGs, in most cases, represent the concentration of a radionuclide in air or water that would limit the dose to the most highly exposed individual to $100 \mathrm{mrem} / \mathrm{yr}$.

Concurrent with the recent development of order 5820 ("Radioactive Waste Management"), DOE Oak Ridge Operations has developed residual contamination guidelines for specific application to DOE's Formerly 
TABLE 2-1

RADIATION PROTECTION STANDARD ${ }^{a}$ AND

RADIOACTIVITY CONCENTRATION GUIDES FOR THE NFSS

Transport Previous Guide

Radionuclide

Medium

(Uncontrolled Areas) New Guide

\begin{tabular}{|c|c|c|c|}
\hline Uranium-Natural & water & $600 \mathrm{pCi} / 1$ & Unchanged $^{b}$ \\
\hline Radium-226 & water & $30 \mathrm{pCi} / 1$ & $\begin{array}{c}1 \times 10^{-7} \mathrm{uCi} / \mathrm{ml} \\
(100 \mathrm{pCi} / 1)\end{array}$ \\
\hline
\end{tabular}

Radon-222 Air Unchanged

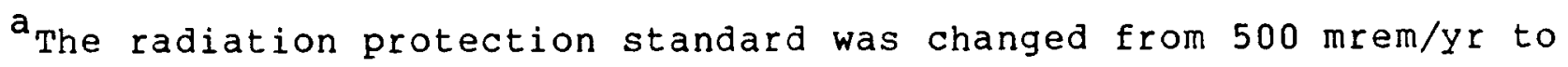
$100 \mathrm{mrem} / \mathrm{yr}$.

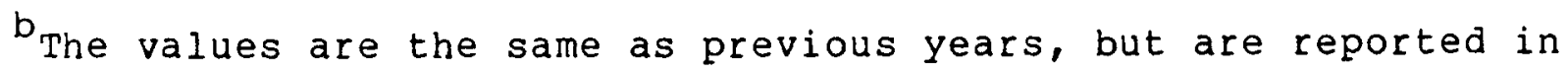
different units. 
Utilized Sites Remedial Action Program (FUSRAP) and for certain Surplus Facilities Management Program (SFMP) sites, such as NFSS, that are remote from other DOE production or research facilities (Ref. 11).

The environmental monitoring program for NFSS as presented in this report is designed to:

- Demonstrate compliance with the requirements of DOE Order 5480.1, Chapters I, XI, and XIII, and with the appropriate criteria specified in the "U.S. Department of Energy Guidelines for Residual Radioactivity at Formerly Utilized Sites Remedial Action Program and Remote Surplus Facilities Management Program Sites" (Ref. 11).

- Determine background levels and contribution from DOE activities of radioactivity and other pollutants in the site environs.

- Determine compliance with applicable environmental quality and public exposure limits and other environmental commitments (e.g., those published in environmental impact statements, Records of Decision, or other official documents).

The following additional guidelines apply to the management of the wastes and/or residues at NFSS.

- Radon concentration in the atmosphere above facility surfaces or openings shall not, (1) exceed $100 \mathrm{pci} / 1$ (above background) for the facility site, or (2) exceed an average radon concentration of $3.0 \mathrm{pci} / 1$ (above background) at or above any location outside the facility site.

\section{Federal Environmental Laws}

Federal environmental statutes that affect the NFSS are the clean Water Act and the Resource Conservation and Recovery Act (RCRA) of 1976. Under Section 404 of the Clean water Act, and 40 CFR 122, a discharge permit is usually required for waste water releases to public waters of the United states. The nonradioactive parameters will be subject to concentration and/or quantity restrictions imposed by permits issued under the National Pollutant Discharge 
Elimination system (NPDES). In New York, the New York State Department of Environmental Conservation (NYSDEC) is fully authorized to administer the NPDES program and, therefore, issues a State pollutant Discharge Elimination system (SPDES) permit. DOE applied for and was issued a permit for the ongoing interim activities at NFSS (DEC Permit \#NY0110469).

The NFSS is not subject to the requirements of RCRA because the stored material is "by-product material" under the Atomic Energy Act of 1954, as amended, and is exempt from RCRA; however, DOE has determined that additional controls should be applied, as necessary, to ensure a degree of protection of the environment and the safety of the public equivalent to that afforded under 40 CFR 260 through 265. Activities to support this decision are described in the closure/post-closure plan (Ref. 7). 


\subsection{SITE DESCRIPTION AND ENVIRONMENT}

\subsection{SITE DESCRIPTION}

Except for nonradioactive boron-10 production conducted at NFSS during 1954 to 1958 and 1964 to 1971, the primary use of the site since 1944 has been for storage of radioactive residues produced as by-products of uranium processing.

The total estimated volume of wastes and residues including uranium processing residues, contaminated soils, and contaminated rubble is approximately $118,560 \mathrm{~m}^{3}\left(156,000 \mathrm{yd}^{3}\right)$ (Ref. 12). This total includes estimates for additional on-site and off-site cleanup which will be completed before the end of 1986 .

The largest portion of the total waste volume is contaminated soil. The major long-lived radioactive contaminants found within the soil are uranium-238, thorium-230, and radium-226. The second largest portion of the total waste volume is the residues which were the result of uranium ore processing. The smallest portion of the total waste volume is the building rubble contaminated with the radioactive constituents found in the residues and soil.

Currently, the residues and the contaminated soil are located in the waste containment area. This area will become the IWCF when construction is completed in 1986. The IWCF is an earthen clay vault structure designed for the containment of the stabilized wastes and residues (Ref. 13). The facility will have an engineered cover designed to minimize water infiltration, radon emanation, and cover erosion. The cover will be sloped to enhance natural drainage away from the storage area. The facility is enclosed by a dike and cutoff wall, each of which are constructed of compacted clay. The cutoff wall is keyed into a low permeability clay layer found beneath the site.

Land use in the immediate vicinity of the NFSS is primarily industrial. Properties bordering the site include a hazardous waste 
disposal site, a sanitary landfill, federal government property used to train construction equipment operators, a power line right-of-way corridor, and several private properties. The nearest residence is located $1.1 \mathrm{~km}(0.7 \mathrm{mi})$ southwest of the site.

Population centers located near the site include the towns of Lewiston, Porter, and Niagara and the city of Niagara Falls. Based on 1980 census data, the estimated population of these municipalities is approximately 104,000 .

\subsection{SITE ENVIRONMENT}

of major importance in the design of an effective environmental monitoring program is consideration of the routes by which contaminants may migrate from a site. Potential routes for the transport of materials from the NFSS include movement through groundwater, air, surface water, and sediment. Contaminants may enter groundwater by infiltration of precipitation, the generation of leachate, and the slow movement through the clay cutoff wall or dike into groundwater. Gaseous radioactive products (i.e., radon-222) may diffuse through the waste containment cover into the atmosphere. Surface water and sediment may receive contaminants by direct seepage from the IWCF or by discharge of groundwater. An understanding of the hydrological and meteorological characteristics (including direction of movement) are important to properly select monitoring locations. These characteristics are described in detail for the site in References 14,15 , and 16 .

The following sections summarize the physical characteristics of each of these environmental media as they apply to the monitoring program for the NFSS and IWCF.

\subsubsection{Groundwater}

Groundwater is found within three aquifers below the site (Refs. 14 and 15). One aquifer lies within the bedrock formation and two lie within the overburden. 
The bedrock aquifer at the site consists of brownish-red shales, siltstone, and mudstone of the Queenston Formation (Figure 3-1). Groundwater movement in the bedrock aquifer generally flows to the west or northwest; however, some apparent anomalies have been observed at various locations within the site boundary (e.g., near the former Building 434 area and in the southwest corner of the site).

One overburden aquifer consists of intermittent sand, gravel, and silt lenses found in a brown clay unit. The other overburden aquifer consists of sand and gravel below a gray clay unit. These zones are shown in Figure 3-1. Water level measurements indicate that groundwater in the lower overburden aquifer generally flows to the northwest, although apparent anomalies in groundwater flow have been observed at some locations (e.g., southwest corner of the site). These anomalies may reflect off-site activities near the site including groundwater extraction or variation in recharge rates.

\section{2 .2 Air}

The NFSS lies within the middle latitude westerlies which results in weather systems moving generally eastward and northeastward through the region. The location of lake ontario considerably moderates the climate in the area.

Meteorological monitoring at the site indicates a prevailing wind direction from the southwest. Wind speeds are predominantly in the 15.9 to $23 \mathrm{~km} / \mathrm{h}(9.9$ to $14.3 \mathrm{mph})$ range. The wind rose for the NFSS in 1985 is provided in Figure $3-2$.

\subsubsection{Surface Water}

Runoff from the NFSS is diverted into three major drainage ditches: the Central Drainage Ditch, the West Ditch, and the South-3l Ditch (Figure 3-3). The west and south-31 ditches discharge directly into the Central Drainage Ditch which flows northward into Fourmile creek and ultimately into Lake ontario. On-site, the central Ditch is 


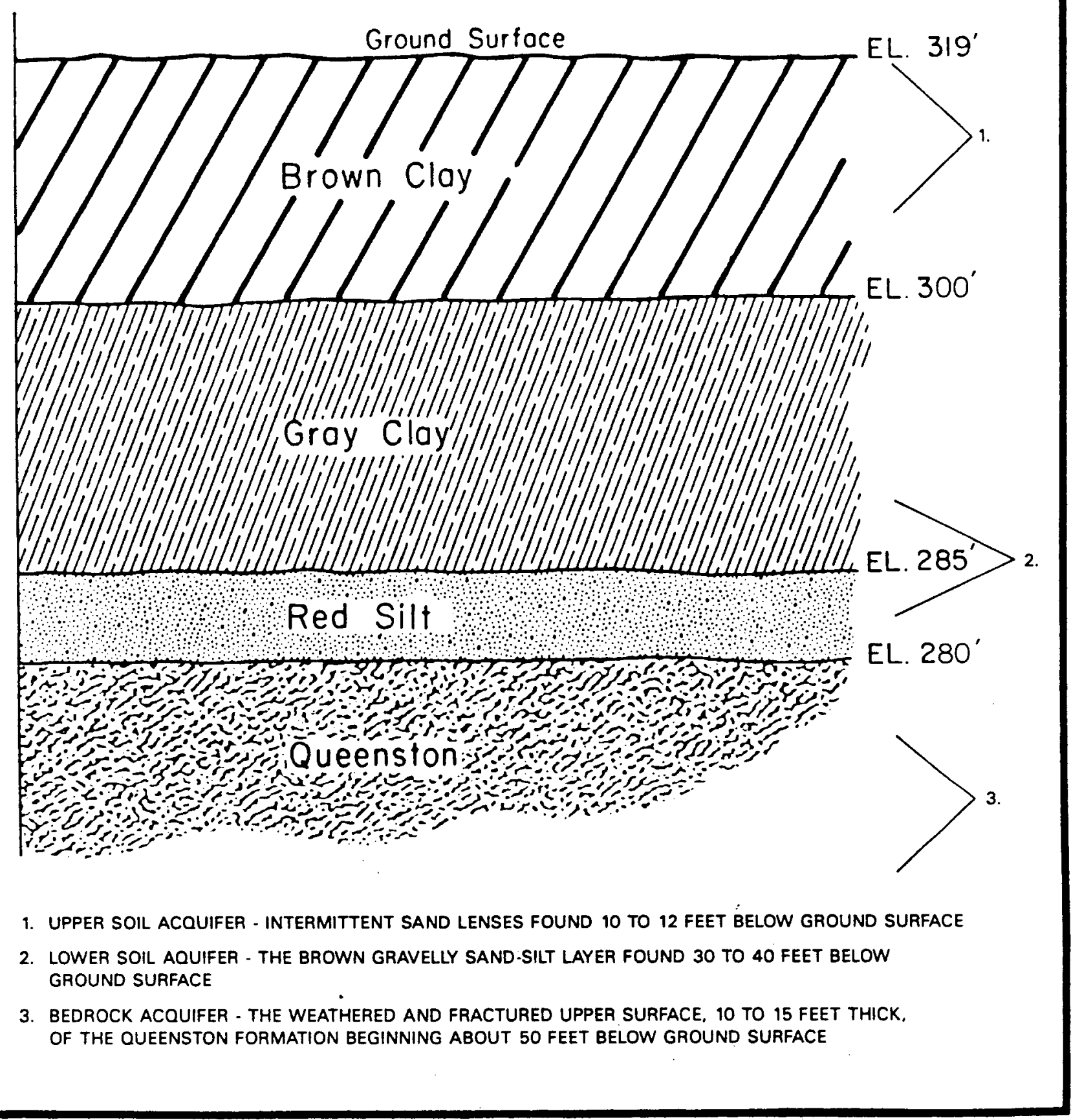

FIGURE 3-1 GENERALIZED GEOLOGIC SECTION OF THE NFSS 


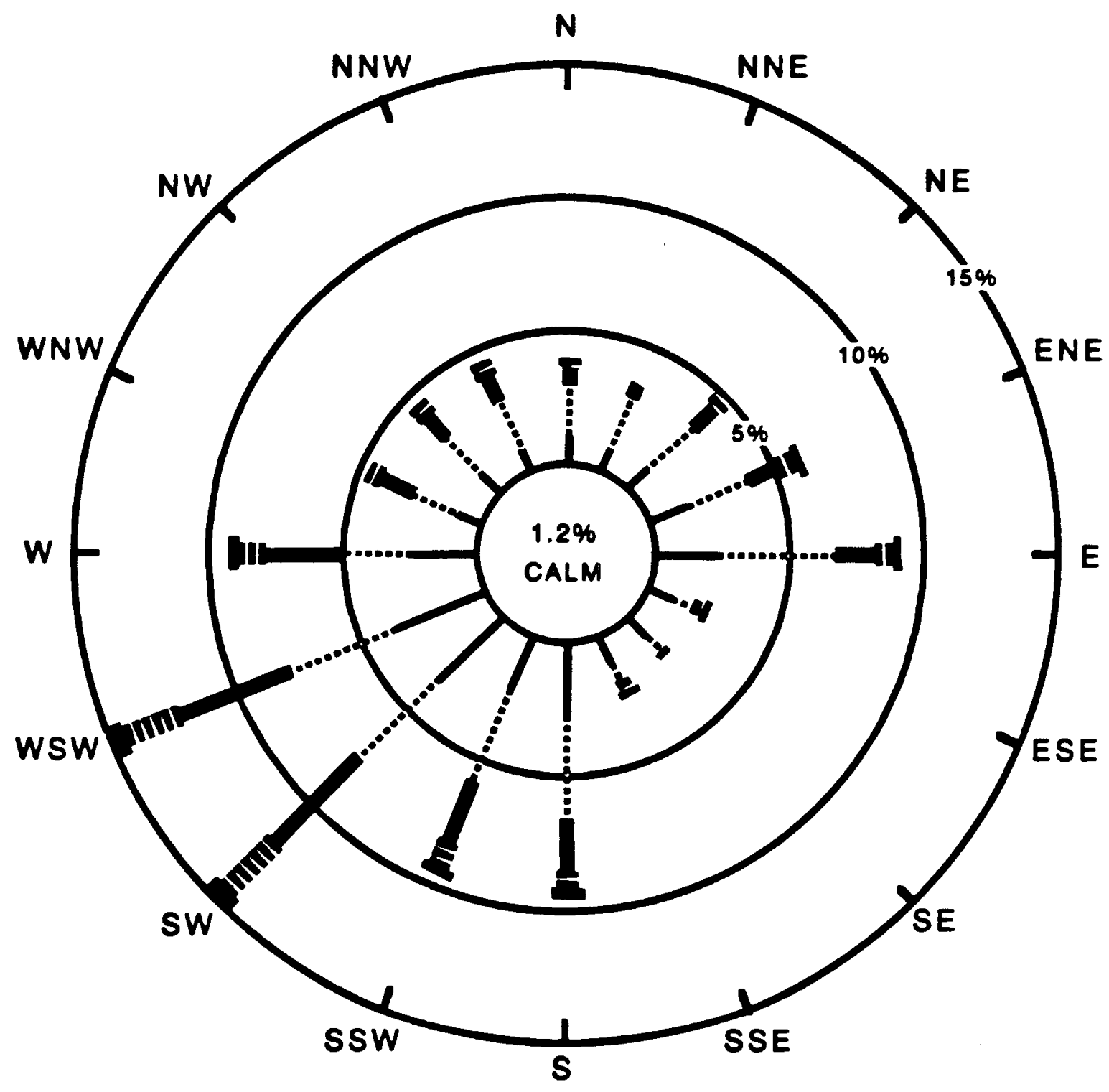

WIND SPEED

MPH 0

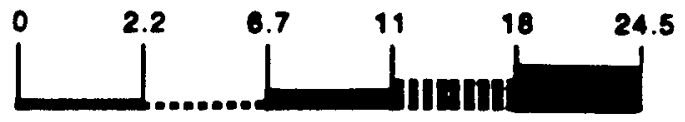

BASED ON DATE FROM

ON - SITE METEOROLOGICAL

STATION DUAING 1085

FIGURE 3-2 ANNUAL WIND ROSE FOR NFSS, 1985 
approximately 3 to $4 \mathrm{~m}$ (10 to $15 \mathrm{ft}$ ) deep, 3 to $6 \mathrm{~m}$ (10 to $20 \mathrm{ft}$ ) wide at the base and 12 to $15 \mathrm{~m}$ ( 40 to $50 \mathrm{ft}$ ) wide at the top.

The 100-yr flood level within NFSS is estimated to be approximately $97 \mathrm{~m}$ ( $319 \mathrm{ft}$ ) m.s.l. The IWCF dike elevation will have a minimum height of $99.9 \mathrm{~m}(325 \mathrm{ft}) \mathrm{m} . \mathrm{s} .1$. Flooding at the site is generally contained within the Central Drainage Ditch (Ref. 17). Major runoff from the site occurs during the spring, and for most of the year, there is very little surface flow. 


\subsection{MONITORING PROGRAM}

Completion of the IWCF in 1986 will result in a major change in the status of NFSS. Based on information obtained from previous monitoring (Refs. 1, 2, 3, 4, and 5), the scope of the monitoring program will be revised to accommodate waste management. Emphasis will be directed toward the sampling and analysis of groundwater, surface water, air, and sediment for parameters which are known to be present or are indicated by materials stored at the site. In addition, gamma radiation will be measured at selected locations around the IWCF and the site perimeter.

The monitoring program will employ a phased approach. The monitoring schedule is provided in Figure 4-1. Monitoring of the NFSS will be conducted quarterly for 5 years after closure of the IWCF. After 5 years, the analytical data will be evaluated with regard to sampling frequency, parameters analyzed, monitoring locations, and concentrations found. The program will be reviewed and modified, as necessary, based upon this evaluation. If a decision is made to manage the wastes for the long term at the site, then periodic monitoring will continue indefinitely.

The following description of the monitoring program is based on available information for the site including characterization studies (Refs. 14, 15, and 16) and the results of previous environmental monitoring efforts (Refs. $1,2,3,4$, and 5). The primary features of the monitoring program are presented in Table 4-1. The program is subject to revision should additional information become available regarding on-site or off-site conditions, or if the site status changes.

\subsection{GROUNDWATER}

Groundwater will be the principal theoretical pathway for migration of contaminants from the IWCF at NFSS. The groundwater monitoring program is designed to detect potential migration of materials from the NFSS as well as monitoring geohydrological conditions. 
TIME (YEARS)

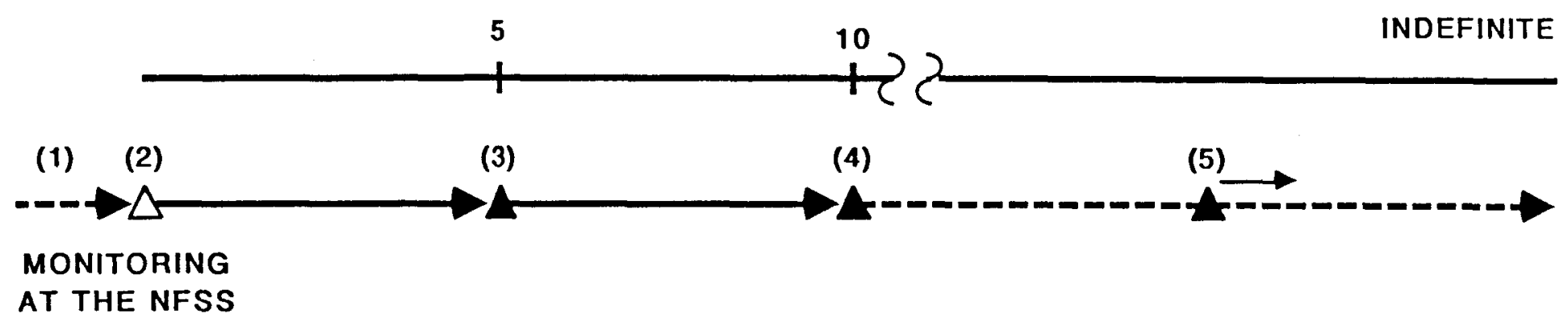

NOTES:

(1) MONITORING BEFORE COMPLETION OF THE IWCF AT NFSS

(2) INITIATE MONITORING PROGRAM FOR NFSS TO ACCOMMODATE COMPLETION OF THE INTERIM WASTE CONTAINMENT FACILITY (IWCF)

(3) DATA EVALUATION TO DETERMINE IF ALTERATIONS TO THE MONITORING PROGRAM (INCLUDING SAMPLING FREQUENCY, MONITORING LOCATIONS AND THE NUMBER OF PARAMETERS) ARE WARRANTED

(4) PROPOSED DURATION OF PERFORMANCE MONITORING PROGRAM EVALUATION OF ENVIRONMENTAL MONITORING PROGRAM.

(5) MONITORING IF REQUIRED FOR LONG - TERM MANAGEMENT

FIGURE 4-1 ENVIRONMENTAL MONITORING SCHEDULE AT THE NFSS 
TABLE 4-1

MONITORING PROGAM FOR THE NFSS

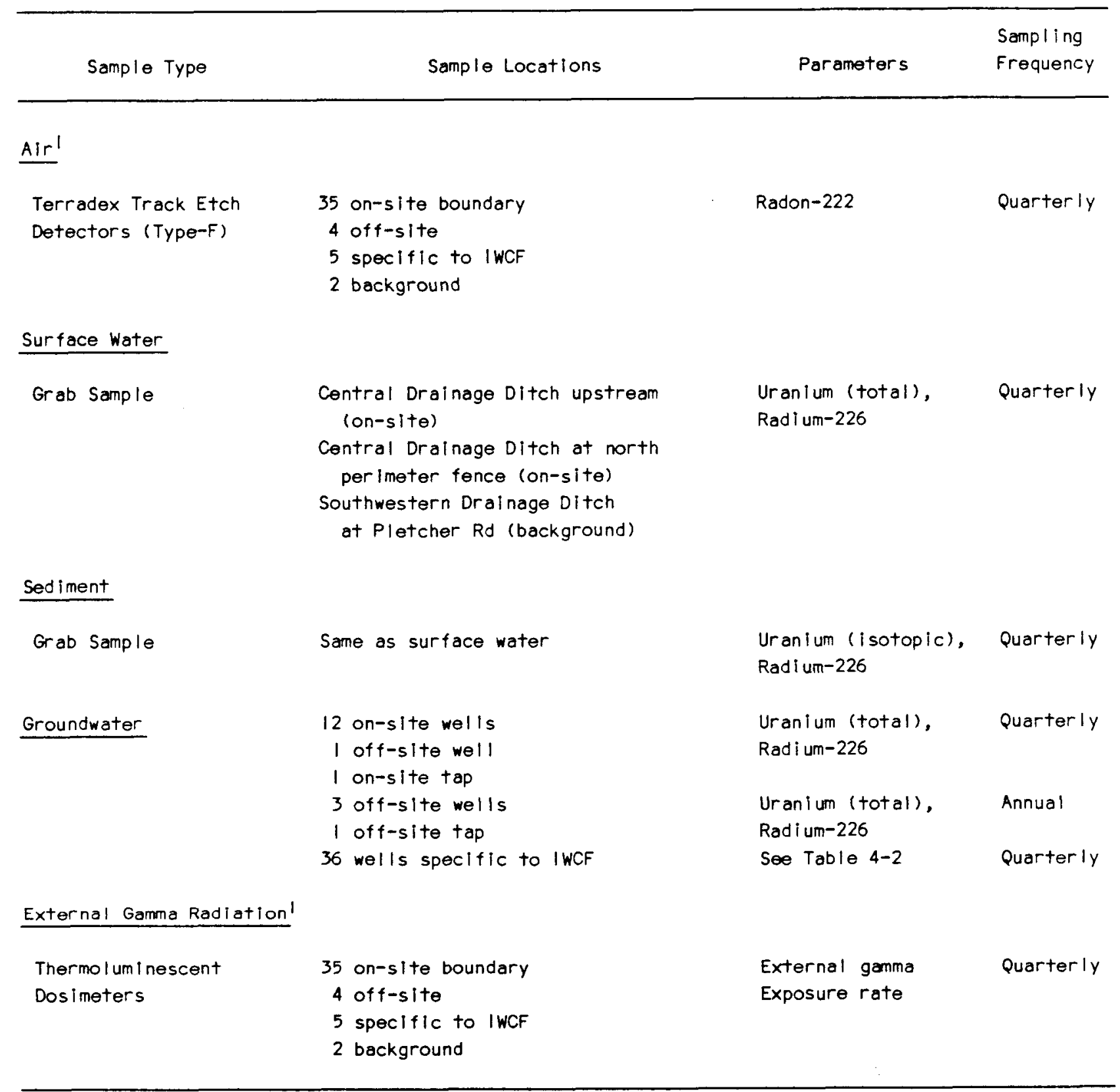

'Background sample location at 610 Seneca Street, Lewiston, NY. 
Groundwater from the overburden aquifers (the upper and lower aquifer) will be monitored for the presence of radionuclides, selected chemicals, and other parameters.

Groundwater monitoring activities will be conducted to meet the following objectives:

- Provide a program for the NFSS in accordance with DOE Order 5484.1 (Ref. 9).

- Verify the performance of the engineered elements of the waste containment structure by providing supplemental monitoring for the performance monitoring system (Ref. 13).

- Provide a program that will meet the substantive requirements of RCRA ( $40 \mathrm{CFR} 264)$ as part of the closure/post-closure plan for the site (Ref. 8).

\subsubsection{Groundwater Monitoring Locations}

The existing groundwater monitoring program includes 16 on-site wells sampled on a quarterly basis and three off-site wells sampled annually (Ref. 4). Samples are analyzed for radium and uranium. The locations of on-site wells in this program are shown in Figure 4-2. Nine wells monitor the lower aquifer, two wells monitor the bedrock aquifer, three wells currently monitor the upper aquifer around the interim waste storage area, and two upgradient wells monitor background. This program will be modified to reflect the completion of remedial action at the site and closure of the IWCF.

To accomplish the objectives noted above, an expanded groundwater monitoring program will be initiated at the NFSs after completion of the IWCF. Eighteen pairs of wells are scheduled to be installed in 1986. One well in each pair will be screened in the shallow aquifer above the gray clay layer while the other well will be screened in the aquifer below the gray clay. The wells will be installed as shown in Figure 4-3. The well in the southeastern corner of the IWCF is located upgradient of the site, and will serve as an indication of background conditions. The remainder of the wells are 


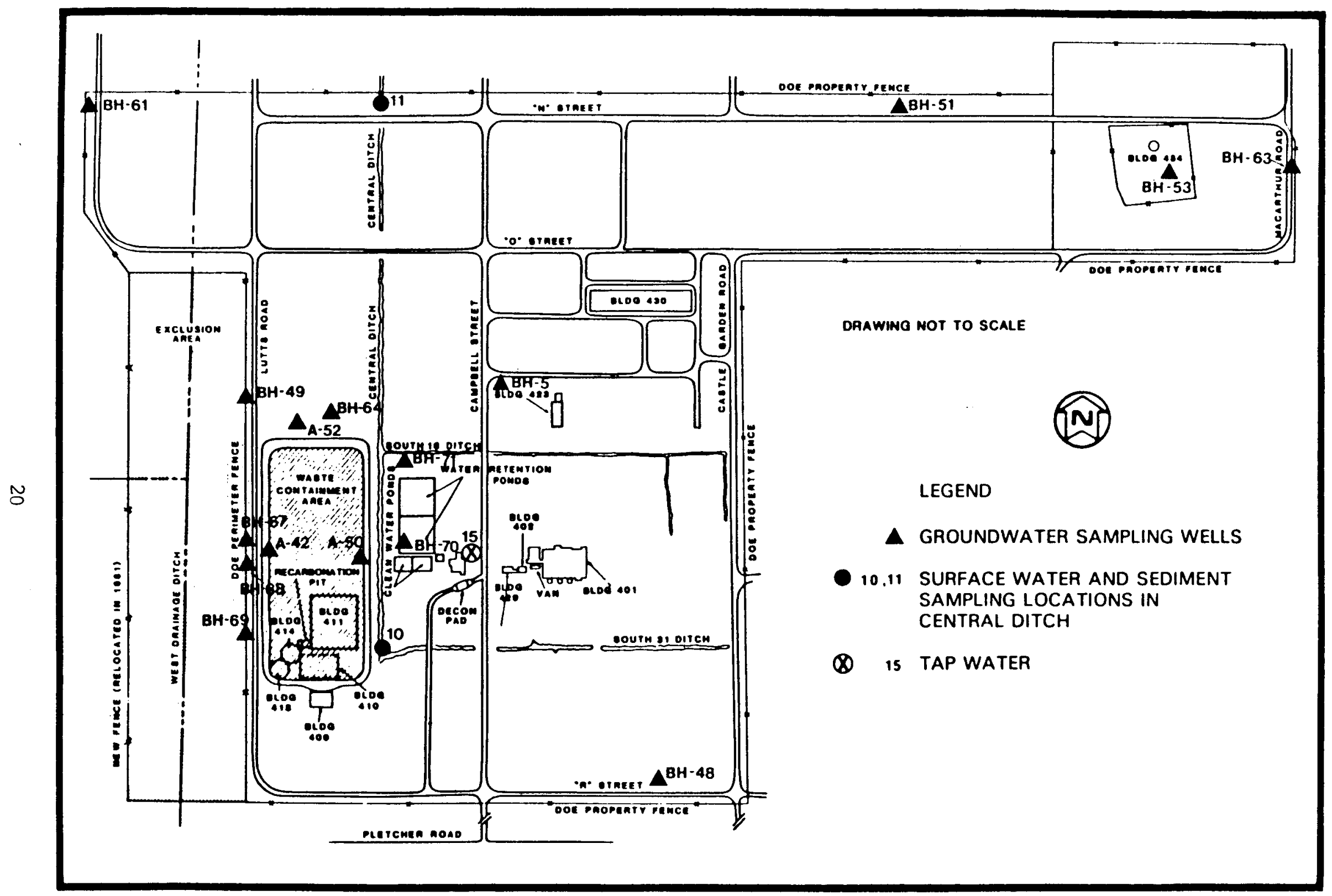

FIGURE 4-2 ON-SITE SURFACE WATER AND GROUNDWATER SAMPLING LOCATIONS 


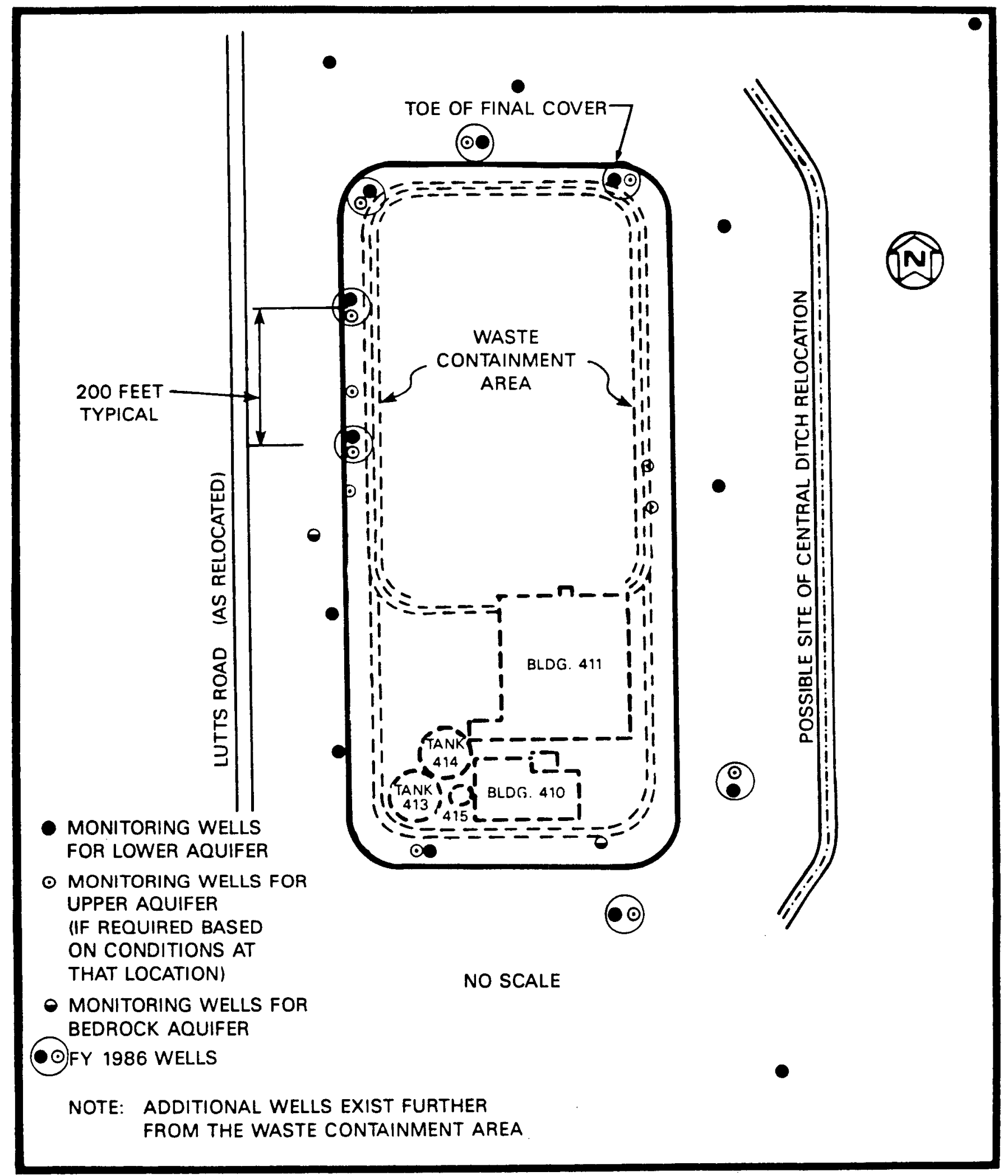

FIGURE 4-3 LOCATIONS OF EXISTING GROUNDWATER WELLS AND WELLS TO BE INSTALLED IN FY 1986 AT THE NFSS 
downgradient of the IWCF. The staggered pattern of two rows of wells approximately $30.5 \mathrm{~m}$ (100 ft) apart, with 61-m (200-ft) spaces between the wells in each row, is designed to ensure detection of any migrating contamination. Well spacings are based on site soil characteristics (e.g., permeability), the groundwater data already collected (e.g., groundwater flow rates and direction), and the conclusions of a groundwater modeling study conducted for the site. As this program is phased in and evaluated over time, most of the wells in the existing program will be replaced.

\subsubsection{Sample Collection and Analysis}

Sample collection and analysis will be conducted following procedures that will meet the substantive requirements of RCRA (40 CFR 264.92-98). The collection, preservation, transportation and analyses of samples will be conducted using approved methods. Chain-of-custody will be maintained on all groundwater samples. Groundwater samples will be collected using equipment dedicated to each well to minimize the potential for cross contamination between wells. Before sample collection, the wells will be purged to ensure that the samples are representative of groundwater in the formation. Where possible, wells will be purged to dryness or a minimum of three times the volume of water standing in the well will be removed prior to sample collection. As a minimum, in wells of very low yield, one volume of water standing in the well will be removed. Field measurements for $\mathrm{pH}$, temperature, and specific conductivity will be made during sample collection.

The recommended parameters to be analyzed for in groundwater samples are listed in Table 4-2. For the wells surrounding the IWCF, samples will be collected and analyzed quarterly for all parameters listed in Table 4-2 for a period of approximately 5 years. For the remaining wells at the NFSS, samples will be collected and analyzed quarterly for the radiological parameters identified in Table $4-2$ for a 5-yr period. Off-site wells will be sampled annually and analyzed for the radiological parameters. Upon completion of 5 years of quarterly monitoring, analytical results will be evaluated 
RECOMMENDED GROUNDWATER PARAMETERS FOR RADIOLOGICAL AND NONRADIOLOGICAL MONITORING OF THE IWCF AT THE NFSS

\section{Parameter}

$\underline{\text { Radiological }}$

Radium-226 and -228 (combined)

Uranium - total

Gross Alpha

(excluding radon and uranium)

Gross Beta

Selected Metals (Stable)

Arsenic

Barium

Cadmium

Chromium (Cr) (Total)

Cobalt

Copper

Iron

Lead

Manganese

Mercury

Molybdenum

Nickel

Selenium

Silver

Zinc

Indicator Parameters

Specific conductance

$\mathrm{pH}$

Total Organic Carbon (TOC)

Total Organic Halogen ( $\mathrm{TOH}, \mathrm{TOX}$ ) 
to determine whether the monitoring frequency and the number of analytical parameters require adjustment. The decision to adjust the frequency of monitoring will be based on the level of each monitored parameter in relation to DOE guidelines (See Table 2-1) and the variability of results. If the monitoring results are below DOE guidelines and are not highly variable, a reduction in monitoring frequency from quarterly to annual may be warranted. The decision to adjust the number of analytical parameters will be based upon a statistical comparison of gross alpha activity with radium-226 and uranium-238 concentrations (or activity). If a significant statistical correlation exists, monitoring during subsequent years will be reduced to include only gross alpha activity. Monitoring will continue annually for gross alpha activity until a decision is made regarding the ultimate disposition of residues at the NFSS.

\section{2 AIR AND EXTERNAL RADIATION}

Air monitoring is designed to detect and quantify the gaseous emission of radon-222 (a decay product of uranium-238). Measurement of radioactive particulates will not be conducted since all remedial action work will have been completed and the cover will prohibit the outward movement of particulates. Monitoring of radon gas will be used to determine compliance with DOE guidelines for radon and to estimate radiological exposure to the general public. This will also verify the effectiveness of the containment structure over time.

Radon-222 will be monitored using Terradex Type F Track-Etch detectors. The detectors are obtained from the Terradex Corporation, placed at the sample locations, collected by site personnel, and then returned to Terradex for analytical services.

\subsubsection{Air Monitoring Locations}

The existing radon monitoring program consists of 34 radon detectors on-site and at site boundary locations as shown in Figure 4-4 (Ref. 4). Limited modifications of this program will occur as the 


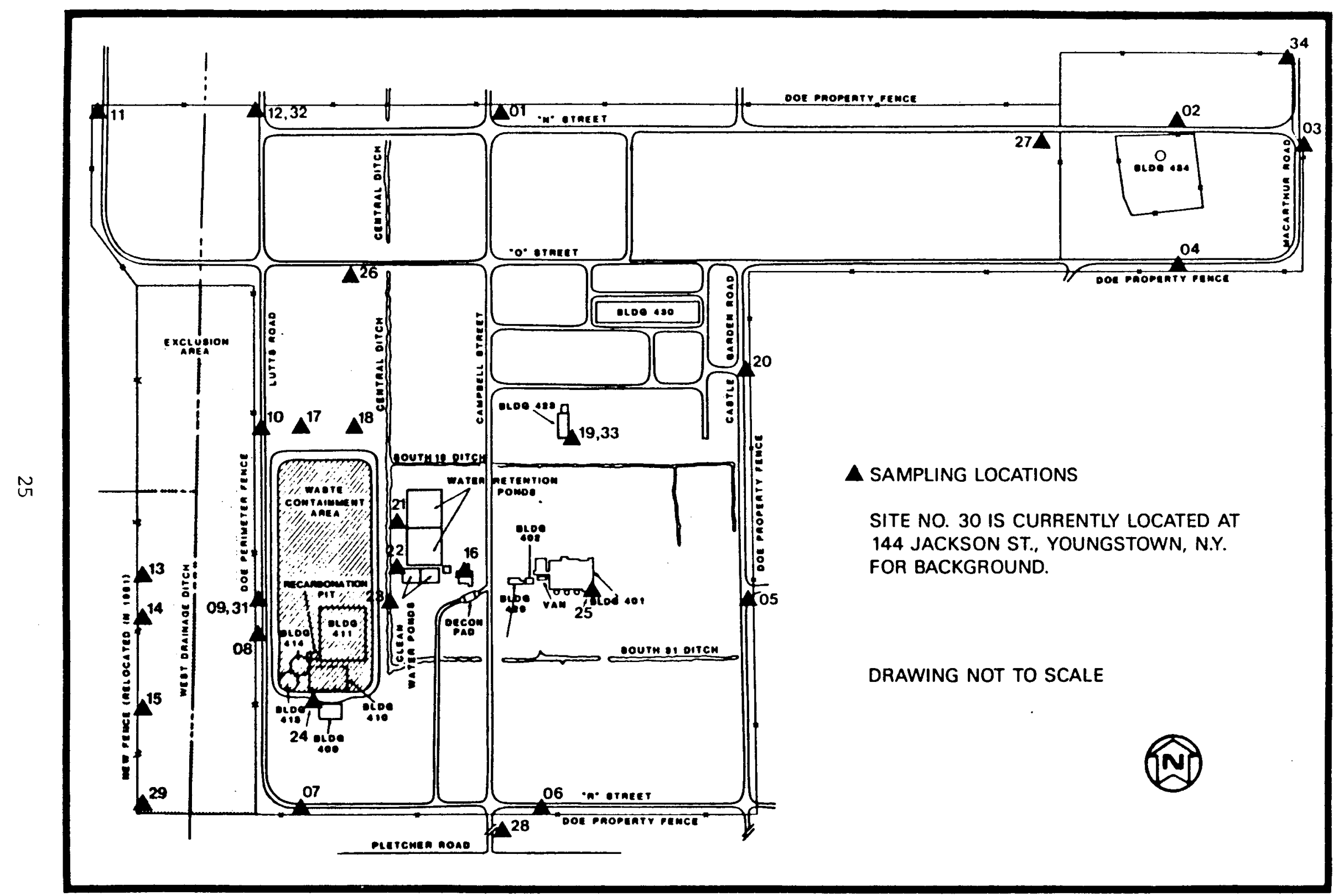

FIGURE 4-4 ON-SITE RADON MONITORING LOCATIONS 
result of the completion of remedial action at NFSS. The location of radon monitors will focus on the site boundary, resulting in a slight reduction of existing on-site monitors.

To accommodate the IWCF, radon detectors will be located around that facility as shown in Figure 4-4. Five additional locations will be added to the nine locations currently around the waste containment area. Four off-site radon monitors will be maintained at the approximate locations shown in Figure 4-5.

\subsubsection{External Radiation Monitoring Locations}

External exposure rates will be measured using lithium-fluoride thermoluminescent dosimeters (TLDs). Each dosimeter will contain five matched chips, the responses of which will be averaged. The dosimeters will be located in conjunction with the Terradex detectors described above.

\subsubsection{Sample collection and Analysis}

For approximately 5 years after completion of the IWCF, the radon detectors and TLDs will be collected and analyzed quarterly. The results will be evaluated to determine whether the monitoring location or frequency require adjustment.

A decision to alter the air and external radiation monitoring program will be based on the level of each monitored parameter relative to DOE criteria and data variability. If the monitoring results are below DOE guidelines and are not highly variable, a reduction in monitoring frequency may be warranted.

\section{3 SURFACE WATER AND SEDIMENT}

Surface water and sediment will continue to be monitored after completion of the IWCF. This monitoring will provide an indication of the adequacy of facility containment over time. 


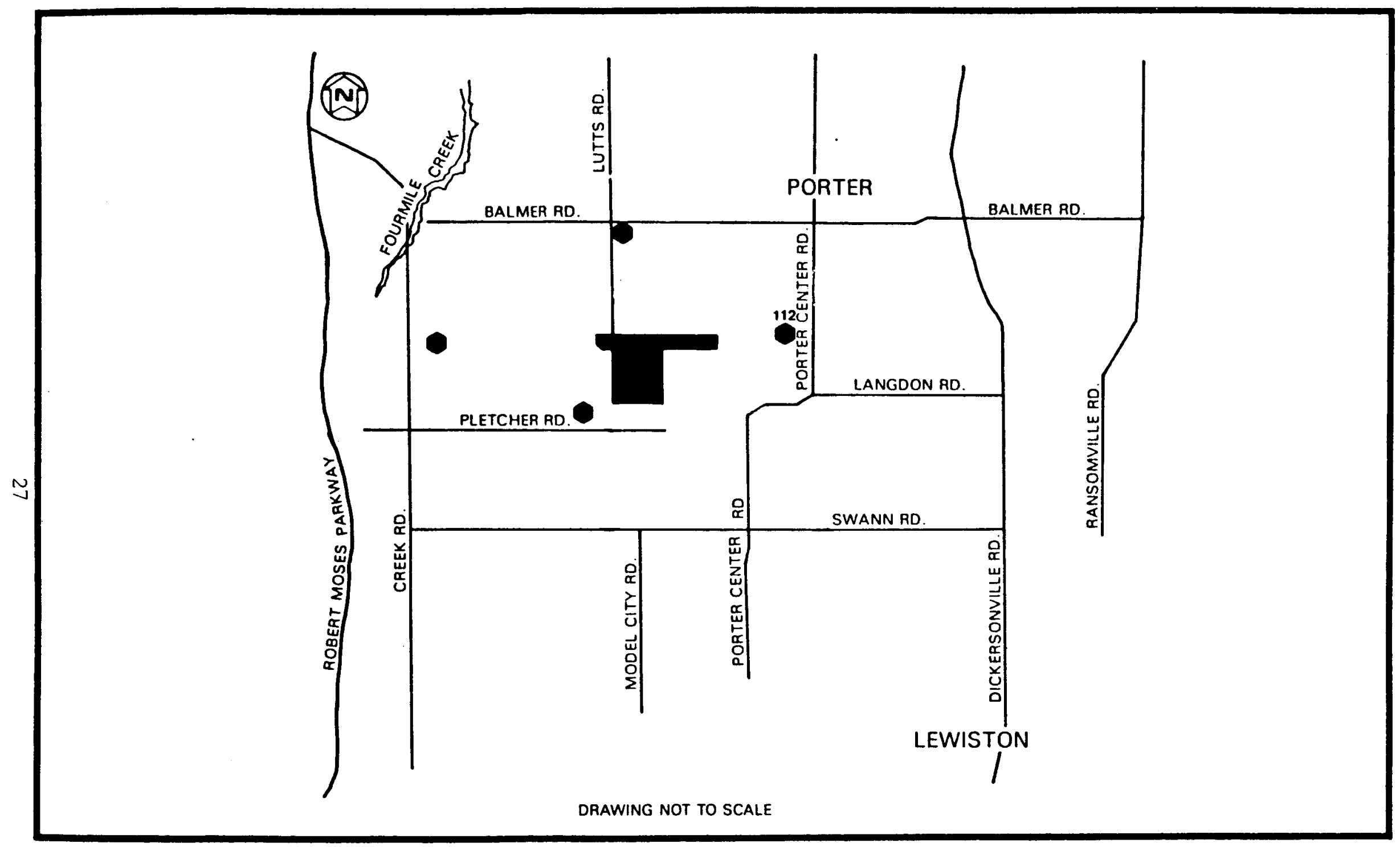

FIGURE 4-5 OFF-SITE RADON MONITORING LOCATIONS 


\subsubsection{Surface Water and Sediment Monitoring Locations}

The major receiving water which collects surface water runoff from the site is the Central Drainage Ditch. Samples of water and sediment will be collected from three locations; one upstream and one downstream of the IWCF and one background location. Approximate locations are indicated in Figure 4-2. The upstream location at the southwest ditch will serve as an indication of background conditions for the NFSS.

\subsubsection{Sample Collection and Analysis}

Grab samples for water and sediment will be collected from the locations indicated in Figure 4-2. Field measurements for $\mathrm{pH}$, temperature, and specific conductivity will be made at the time of sample collection. surface sediments (which are the most prone to scour and transport) will be collected using a stainless steel scoop. Sediment samples will be analyzed for isotopic uranium and radium-226; water samples will be analyzed for total uranium, radium-226, and gross alpha activity.

As for groundwater monitoring (Section 4.1.2), 5 years of quarterly monitoring results will be evaluated to determine whether the monitoring frequency and the number of analytical parameters require adjustment. The decision to adjust the frequency of monitoring will be based on the level of each monitored parameter in relation to DOE guidelines (see Table 2-1) and the variability of results. If the monitoring results are below DOE guidelines and are not highly variable, a reduction in monitoring frequency from quarterly to annually may be warranted. The decision to adjust the number of analytical parameters will be based upon a statistical comparison of gross alpha activity with radium-226 and uranium-238 concentrations (or activity). If a significant statistical correlation exists, monitoring during subsequent years will be reduced to include only gross alpha activity. 


\subsection{DATA EVALUATION AND REPORTING}

An environmental monitoring report will be prepared and distributed annually according to the requirements of DOE order 5484.1. The report will summarize and interpret the levels of radioactivity and nonradioactive pollutants in the environs of the NFSS.

A summary of the year's monitoring data will be provided indicating the mean value and the range for each parameter. Data will be evaluated to determine compliance with DOE guidelines and other applicable environmental standards and comparisons will be made with background radioactivity. The data will also be used to evaluate radiological exposure to members of the general public.

The report will provide the type and frequency of samples, methods of analyses, quality assurance program description, and analytical data as required for applicable DOE guidelines.

The environmental monitoring report will also summarize the results of monitoring to determine compliance with applicable nonradiological effluent standards and permit conditions. The results of any pertinent environmental surveys conducted by other federal, state, or local environmental protection agencies (as available) will also be summarized. 
1. Bechtel National, Inc. Niagara Falls Storage Site (NFSS) Environmental Monitoring Report, Calendar Year 1981, 10-05-202-001, Oak Ridge, TN, May 1983.

2. Bechtel National, Inc. Niagara Falls Storage Site (NFSS) Environmental Monitoring Report, Calendar Year 1982, 10-05-202-002, Oak Ridge, TN, May 1983.

3. Bechtel National, Inc. Niagara Falls Storage Site Environmental Monitoring Report, Calendar Year 1983, DOE/OR/20722-18, Oak Ridge, TN, July 1984 .

4. Bechtel National, Inc. Niagara Falls Storage Site Environmental Monitoring Report, Calendar Year 1984, DOE/OR/20722-55, Oak Ridge, TN, July 1985.

5. Bechtel National, Inc. Niagara Falls storage Site Environmental Monitoring Report, Calendar Year 1985, DOE/OR/20722-98, Oak Ridge, TN, April 1986.

6. Bechtel National, Inc. Report on the Performance Monitoring System for the Interim waste containment at the Niagara Falls Storage Site, DOE/OR/20722-71, Oak Ridge, TN, October 1985.

7. Bechtel National, Inc. Closure/Post-Closure Plan for the Interim Waste Containment Facility at the Niagara Falls storage Site, DOE/OR/20722-85 (Draft), Oak Ridge, TN, November 1985 .

8. U.S. Department of Energy. DOE Order 5484.1, Environmental Protection, Safety, and Health Protection Information Reporting Reguirements, Washington, DC, February 24, 1981. 
9. U.S. Department of Energy (DOE). DOE Order 5480.1A, Environmental Protection, Safety, and Health Protection Program for DOE Operations, Washington, DC, August 13, 1981 .

10. Memorandum. R.J. Stern, Department of Energy, to Distribution, - Preparation of Annual Site Environmental Reports for Calendar Year 1985" (Attachment: DOE-Derived Concentration Guides for Drinking water and Breathing Air Contaminated with Radionuclides by Members of the Public), February 26, 1986.

11. Letter, John E. Baublitz, Jr. to E.L. Keller. "Guidelines for Residual Radioactivity at FUSRAP and Remote SFMP Sites" (Attachment: U.S. Department of Energy Guidelines for Residual Radioactivity at Formerly Utilized Sites Remedial Action Program and Remote Surplus Facilities Management Program Sites, Rev. I, July 1985), July 22, 1985.

12. U.S. Department of Energy. Niagara Falls Storage Site Project Management Plan, ORO-845 (Draft), Rev.1, Oak Ridge, TN, May 1985.

13. Bechtel National, Inc. Design Report for the Waste Containment Facility at the Niagara Falls storage Site, DOE/OR/20722-21 (Draft), Oak Ridge, TN, July 1985.

14. Bechtel National, Inc. Geologic Report, Niagara Falls Storage Site, Lewiston, New York, DOE/OR/20722-8, Oak Ridge, TN, June 1984.

15. Acres American, Inc. Hydrologic and Geologic Characterization of the DOE-Niagara Falls Storage site, Buffalo, NY, September 1981 .

16. Battelle Columbus Laboratories. A Comprehensive Characterization and Hazard Assessment of the DOE-Niagara Falls Storage Site, BMI-2074 (Revised), Columbus, OH, June 1981. 
17. U.S. Department of Energy. Environmental Impact Statement-Long-Term Management of the Existing Radioactive Wastes and Residues at the Niagara Falls storage Site, DOE/EIS-0109F, Washington, D.C., April 1986. 